Abstracta Iranicacta Iranica

Revue bibliographique pour le domaine irano-aryen

Volume 32-33 | 2013

Comptes rendus des publications de 2009-2010

\title{
Martin Heimgartner. Timotheos I., Ostsyrischer Patriarch: Disputation mit dem Kalifen Al-Mahdi
}

\section{Christelle Jullien}

\section{(2) OpenEdition}

12 Journals

\section{Édition électronique}

URL : http://journals.openedition.org/abstractairanica/40833

DOI : 10.4000/abstractairanica.40833

ISSN : 1961-960X

Éditeur :

CNRS (UMR 7528 Mondes iraniens et indiens), Éditions de l'IFRI

\section{Édition imprimée}

Date de publication : 1 décembre 2013

ISSN : 0240-8910

\section{Référence électronique}

Christelle Jullien, « Martin Heimgartner. Timotheos I., Ostsyrischer Patriarch: Disputation mit dem Kalifen Al-Mahdi », Abstracta Iranica [En ligne], Volume 32-33 | 2013, document 325, mis en ligne le 01 juillet 2016, consulté le 03 octobre 2020. URL : http://journals.openedition.org/abstractairanica/40833 ; DOl : https://doi.org/10.4000/abstractairanica.40833

Ce document a été généré automatiquement le 3 octobre 2020.

Tous droits réservés 


\title{
Martin Heimgartner. Timotheos I., Ostsyrischer Patriarch: Disputation mit dem Kalifen Al-Mahdi
}

\author{
Christelle Jullien
}

\section{RÉFÉRENCE}

Martin Heimgartner. Timotheos I., Ostsyrischer Patriarch: Disputation mit dem Kalifen AlMahdi. Louvain, Peeters, 2009, XX-165 p., LXVI-123 p. (Corpus Scriptorum Christianorum Orientalium 631-632, Scriptores Syri 244-245).

1 Ce travail constitue l'édition critique référente (syriaque et traduction allemande) pour ce texte, l'un des plus importants de la littérature de polémique islamo-chrétienne du $\mathrm{VIII}^{\mathrm{e}}$ siècle. Il fut rédigé vers 782-783, fruit d'une disputatio entre le patriarche de l'Église syro-orientale Timothée $\mathrm{I}^{\text {er }}$ et le troisième calife abbasside al-Mahdi sur des questions théologiques et exégétiques, en particulier christologiques, mais aussi sur la conception de l'histoire du salut et de la légitimité de sa continuité. Le texte syriaque de l'Apologie avait été une première fois publié en 1928 par Alphonse Mingana dans les Woodbrooke Studies, avec une traduction anglaise; signalons qu'il vient d'être tout récemment réédité par les éditions Gorgias Press (2009) : A. Mingana, The Apology of Timothy the Patriarch before the Caliph Mahdi, 332 p. L'A. en donne ici le fac-simile. 


\section{AUTEURS}

\section{CHRISTELLE JULLIEN}

CNRS, Mondes iranien et indien, Paris 